\title{
Perencanaan Bangunan Pemecah Gelombang di Teluk Sumbreng, Kabupaten Trenggalek
}

\author{
Dzakia Amalia Karima dan Bambang Sarwono \\ Jurusan Teknik Sipil, Fakultas Teknik Sipil dan Perencanaan, Institut Teknologi Sepuluh Nopember (ITS) \\ e-mail: sarwonobambang@yahoo.com
}

\begin{abstract}
Abstrak - Kabupaten Trenggalek yang beribukota di Trenggalek memiliki luas 126.140 Ha yang terbagi dalam 152 Kelurahan/Desa dan 14 Kecamatan. Yang menjadi lokasi studi yaitu di Teluk Sumbreng, Kecamatan Munjungan, Kabupaten Trenggalek. Lokasi ini memiliki potensi perikanan berupa pantai sepanjang $96 \mathrm{~km}$, ketersediaan ikan cukup melimpah. Untuk memanfaatkan potensi ini dengan maksimal, pemerintah akan membangun sebuah pelabuhan sebagai sarana bagi para nelayan. Namun, diperlukan pula sarana pendukung untuk dapat menunjang kegiatan di pelabuhan itu sendiri. Salah satunya yaitu dengan membuat bangunan pemecah gelombang yang berfungsi untuk melindungi perairan di dermaga dapat tenang dan memudahkan mobilitas nelayan. Dalam perencanaan bangunan pemecah gelombang, hal yang perlu diperhatikan adalah data primer dan sekunder. Data sekunder tersebut antara lain data angin, data pasang surut, peta topografi dan batimetri di sekitar lokasi tinjau. Kemudian data-data tersebut dianaliisa untuk mendapatkan kondisi tinggi gelombang di lokasi yang akan dibangun. Data angin dianalisis menggunakan proses hindcasting sehingga didapat tinggi gelombang signifikan di laut dalam. Data pasang surut dianalisis menggunakan Metode Admiralty dan didapatkan elevasi-elevasi untuk perencanaan bangunan. Data topografi dan batimetri diperlukan untuk mendapatkan kedalaman perairan di lokasi perencanaan.Selanjutnya direncanakan bangunan pemecah gelombang. Setelah semua analisis dilakukan, dapat dihasilkan dimensi dan gambar desain hasil perencanaan bangunan pemecah gelombang. Dari hasil perencanaan tersebut juga diharapkan dapat menjadi solusi untuk melindungi pelabuhan yang ada di Teluk Sumbreng.
\end{abstract}

Kata Kunci-Gelombang, Pelabuhan, Pemecah Gelombang, Teluk Sumbreng.

\section{PENDAHULUAN}

I NDONESIA merupakan negara kepulauan yang terdiri dari 13.466 pulau dan wilayah pantai sepanjang $99.093 \mathrm{~km}$. Wilayah pantai ini merupakan kawasan yang sangat intensif dimanfaatkan oleh manusia terutama untuk kegiatan industri, pelabuhan, pertambakan, perikanan, dan pariwisata. Untuk mendukung kegiatan-kegiatan tersebut mengakibatkan kebutuhan akan lahan dan prasarana meningkat.

Secara umum pembangunan di bidang perikanan dilakukan melalui serangkaian kebijakan. Di bawah Kementerian Kelautan dan Perikanan, pembangunan di bidang perikanan diorientasikan untuk meningkatkan tata pemanfaatan sumber daya ikan, mengembangkan sarana dan prasarana perikanan, meningkatkan pelayanan usaha dan pengendalian usaha perikanan, meningkatkan mutu dan nilai tambah hasil perikanan serta mengembangkan usaha perikanan skala kecil.
Pengembangan di bidang perikanan masih dihadapkan dengan berbagai permasalahan di masa depan. Seperti minimnya sarana dan prasarana, terjadi kerusakan lingkungan ekosistem air laut dan pesisir, dan masih terbatasnya akses nelayan ke sumber daya produktif termasuk permodalan dan layanan usaha yang pada akhirnya berdampak pada rendahnya kesejahteraan nelayan. Dengan minimnya sarana dan prasarana yang menunjang aktivitas nelayan, maka pengembangan di bidang perikanan akan terhambat. Oleh karena itu, permasalahan tersebut menjadi sebuah tantangan untuk semakin mengakselerasikan pembangunan di bidang perikanan di masa mendatang.

Kabupaten Trenggalek yang beribukota di Trenggalek memiliki luas 126.140 Ha yang terbagi dalam 152 Kelurahan/Desa dan 14 Kecamatan. Yang menjadi lokasi studi untuk studi ini yaitu di Teluk Sumbreng, Kecamatan Munjungan, Kabupaten Trenggalek sebagaimana dapat dilihat pada Gambar 1.

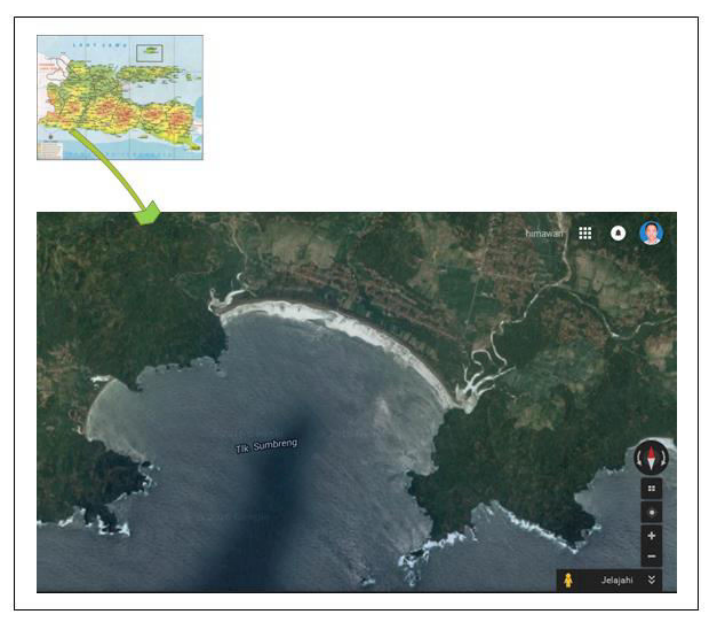

Gambar 1. Peta Teluk Sumbreng, Kabupaten Trenggalek

Pada daerah studi Kecamatan Munjungan, Kabupaten Trenggalek, yang memiliki potensi perikanan berupa pantai sepanjang $96 \mathrm{~km}$, ketersediaan ikan cukup melimpah. Potensi ini sudah selayaknya dapat dimanfaatkan semaksimal mungkin untuk memenuhi kebutuhan sumber pangan masyarakat Kabupaten Trenggalek secara mandiri. Pemerintah Daerah akan membangun pelabuhan sebagai sarana bagi para nelayan untuk menunjang kegiatan perikanan. Namun, diperlukan pula sarana pendukung untuk dapat memaksimalkan kegiatan di bidang perikanan. Salah satunya yaitu dengan membuat bangunan pemecah gelombang (breakwater). Bangunan pemecah gelombang merupakan 
konstruksi yang bisa dibangun sejajar atau tegak lurus dengan garis pantai yang berfungsi untuk melindungi perairan dibelakangnya terhadap serangan gelombang. Bangunan Pemecah Gelombang ini direncanakan agar memudahkan bersandarnya kapal nelayan serta kegiatan bongkar muat hasil tangkapan ikan di pelabuhan.

Berikut perumusan masalah dari studi ini:

1. Bagaimana kondisi iklim gelombang dan pasang surut di daerah Pantai Teluk Sumbreng?

2. Berapa kedalaman perairan di lokasi perencanaan?

3. Berapa tinggi gelombang di laut dalam dan tinggi gelombang rencana yang akan bekerja pada bangunan pemecah gelombang?

4. Berapa dimensi struktur bangunan pemecah gelombang?

\section{METODOLOGI}

Dengan alir perencanaan bangunan pemecah gelombang pada studi ini dapat dilihat pada Gambar 2.

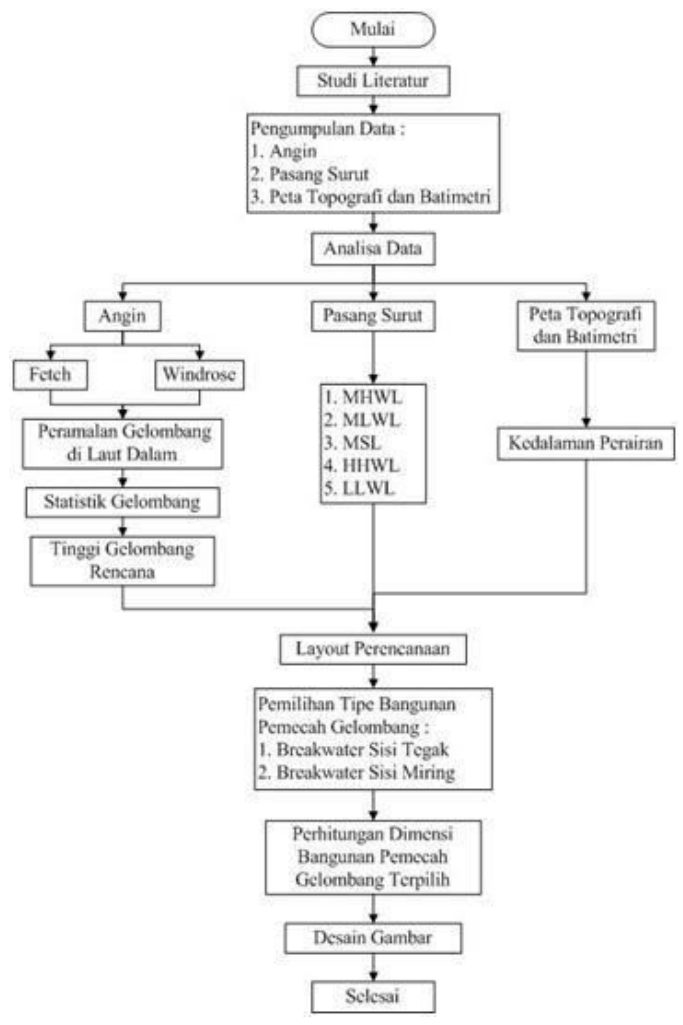

Gambar 2. Diagram Alir Perencanaan Pemecah Gelombang.

\section{HASIL DAN PEMBAHASAN}

\section{A. Gelombang}

\section{Analisis Data Angin}

Data angin digunakan untuk menentukan arah dan tinggi gelombang. Data yang diperlukan adalah data arah dan kecepatan angin dimana data tersebut didapatkan dari Stasiun Meteorologi tahun 2010-2014. Dari data tersebut dibuat dalam bentuk gambar windrose menggunakan aplikasi WRPLOT seperti pada Gambar 3 berikut ini.

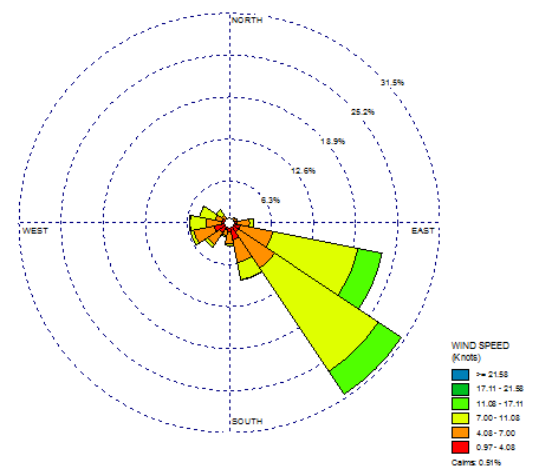

Gambar 3. Windrose Teluk Sumbreng, Kabupaten Trenggalek Tahun 20102014

\section{Analisis Fetch}

Fetch merupakan panjang daerah pembangkitan gelombang di laut. Fetch dibatasi oleh bentuk daratan yang mengelilingi laut. di daerah pembentukan gelombang tidak hanya dibangkitkan dalam arah yang sama dengan arah angin, tetapi juga dalam berbagai sudut terhadap arah angin. Fetch rerata efektif diberikan oleh persamaan berikut [1]:

Dimana:

$$
F_{\text {eff }}=\frac{\sum(\mathrm{Xi} \cdot \cos \alpha \mathrm{i})}{\sum \cos \alpha \mathrm{i}}
$$

$F_{\text {eff }}=$ fetch rerata efektif

$\mathrm{Xi}=$ panjang segmen fetch yang diukur dari titik observasi gelombang ke ujung akhirfetch

$\alpha_{\mathrm{i}} \quad=$ deviasi pada kedua sisi arah angin dengan menggunakan pertambahan $6^{\circ}$ sampai sudut $42^{\circ}$ pada kedua sisi dari arah angin

Fetch rerata efektif yang diperhitungkan dalam studi ini adalah dari arah Tenggara dan Timur.

$F_{\text {eff }}$ Tenggara $=1074.119 \mathrm{~km}$

$F_{\text {eff }}$ Timur $=139.496 \mathrm{~km}$

3. Tinggi dan Periode Gelombang pada Laut Dalam

Untuk menghitung tinggi gelombang digunakan analisis hindcasting. Metode yang digunakan yaitu metode yang dijelaskan di dalam CEM (Coastal Engineering Manual, 1984) [2]. Perhitungan tinggi gelombang dihitung berdasarkan diagram alir pada Gambar 4.

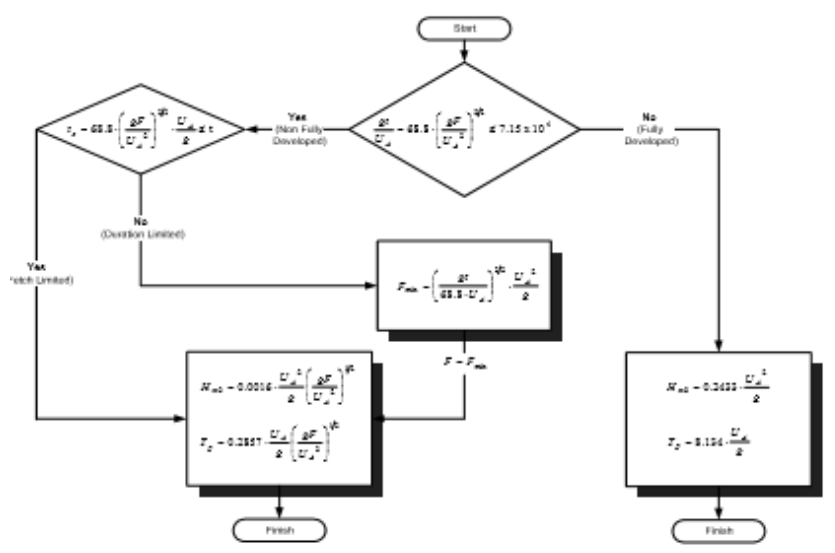

Gambar 4. Diagram Alir Proses Hindcasting. 
Dari hasil analisis hindcasting didapat tinggi gelombang signifikan $\mathrm{H}_{33}$ tertinggi senilai 3.219 m dengan periode 9.446 detik. Terjadi pada Tahun 2014. Kemudian dari tinggi gelombang signifikan tiap tahun dihitung tinggi gelombang $\mathrm{H}_{10}$ yang akan digunakan untuk perencanaan bangunan pemecah gelombang dengan dikalikan 1,28. Dari hasil $\mathrm{H}_{10}$ yang didapat tiap tahun akan digunakan untuk perkiraan gelombang dengan periode ulang.

\section{Perkiraan Gelombang dengan Periode Ulang Metode} Weibull

Perkiraan gelombang dengan periode ulang menggunakan Metode Weibull [1]:

$$
P(H s \leq H s m)=1-\frac{\mathrm{m}-0,2-\frac{0,27}{\sqrt{\mathrm{k}}}}{\mathrm{NT}+0,2+\frac{0,23}{\sqrt{\mathrm{k}}}}
$$

Perhitungan periode ulang menggunakan tinggi gelombang $\mathrm{H}_{10}$ yang sudah diurutkan pada Tabel 1 . Hasil perhitungan dapat dilihat pada Tabel 2.

Tabel 1.

Tinggi Gelombang $\mathrm{H}_{10}$ yang Sudah Diurutkan

\begin{tabular}{|c|c|c|c|c|}
\hline \multirow{2}{*}{ No. } & \multirow{2}{*}{ Tahun } & \multicolumn{3}{|c|}{ Gelombang Representatif } \\
\cline { 3 - 5 } & & $\mathrm{H}_{\mathrm{t} 0}(\mathrm{~m})$ & $\mathrm{Tm}(\mathrm{s})$ & arah \\
\hline 1 & 2005 & 2.7 & - & - \\
\hline 2 & 2006 & 3.1 & - & - \\
\hline 3 & 2007 & 3.1 & - & - \\
\hline 4 & 2008 & 4.2 & - & - \\
\hline 5 & 2009 & 3.4 & - & - \\
\hline 6 & 2010 & 1.182 & 6.477 & $\mathrm{SEE}$ \\
\hline 7 & 2011 & - & - & - \\
\hline 8 & 2012 & 3.296 & 10.814 & $\mathrm{SE}$ \\
\hline 9 & 2013 & 3.460 & 11.080 & $\mathrm{SE}$ \\
\hline 10 & 2014 & 4.120 & 12.091 & $\mathrm{SE}$ \\
\hline
\end{tabular}

Tabel 2.

Tinggi Gelombang Periode Ulang 50 Tahun Metode Weibull

\begin{tabular}{|c|c|c|c|c|c|c|}
\hline $\mathrm{T}_{\mathrm{r}}$ & $\mathrm{y}_{\mathrm{r}}$ & $\mathrm{H}_{s r}$ & \multirow{2}{*}{ on } & \multirow{2}{*}{ or } & $\mathrm{H}_{s r}-1.28 \times \mathrm{s} \mathrm{s}_{r}$ & $\mathrm{H}_{s r}+1.28 \times \mathrm{s}_{\mathrm{r}}$ \\
\cline { 1 - 2 } (tahun) & (tahun) & $(\mathrm{m})$ & & & $(\mathrm{m})$ & $(\mathrm{m})$ \\
\hline 5 & 1.054 & 3.349 & 0.547 & 0.485 & 2.728 & 3.970 \\
\hline 10 & 1.097 & 3.401 & 0.569 & 0.505 & 2.754 & 4.048 \\
\hline 15 & 1.117 & 3.425 & 0.580 & 0.515 & 2.767 & 4.084 \\
\hline 20 & 1.130 & 3.441 & 0.587 & 0.521 & 2.774 & 4.108 \\
\hline 25 & 1.139 & 3.452 & 0.592 & 0.525 & 2.780 & 4.124 \\
\hline 30 & 1.146 & 3.460 & 0.596 & 0.529 & 2.784 & 4.137 \\
\hline 50 & 1.164 & 3.482 & 0.606 & 0.537 & 2.794 & 4.170 \\
\hline 75 & 1.176 & 3.498 & 0.613 & 0.544 & 2.802 & 4.194 \\
\hline 100 & 1.185 & 3.508 & 0.618 & 0.548 & 2.807 & 4.210 \\
\hline
\end{tabular}

Tinggi gelombang periode ulang 50 tahun menggunakan Metode Weibull yaitu sebesar $3.482 \mathrm{~m}$ dengan periode gelombang 11.116 detik.

\section{Analisis Refraksi}

Dari tinggi gelombang periode ulang 50 tahun, kemudian dilakukan analisis refraksi untuk mendapatkan tinggi gelombang di lokasi perencanaan bangunan akibat pendangkalan yang disebabkan oleh perbedaan ketinggian elevasi dasar perairan. Metode analisis refraksi yang digunakan adalah metode puncak gelombang. Pembuatan diagram refraksi dengan metode puncak gelombang dijelaskan di dalam Buku Teknik Pantai (Bambang Triatmodjo, 2016) [1]:

1)Dimulai dari garis puncak gelombang di laut dalam (ditetapkan sejumlah titik di sepanjang garis puncak gelombang)

2)Berdasarkan kedalaman air di titik-titik tersebut, kemudian dihitung panjang gelombang dengan bantuan tabel L-1, didapat panjang gelombang masing-masing titik yang tegak lurus dengan garis puncak gelombang (atau garis singgungnya)

3) Kemudian ujung-ujung panjang gelombang tersebut dapat ditarik garis yang menjadi garis puncak geombang berikutnya

4)Prosedur ini diulangi terus sampai akhirnya garis orthogonal gelombang mencapai garis pantai

Gelombang yang direfraksikan adalah gelombang dari arah Tenggara karena angin pada arah tersebut dominan dan berpengaruh ke lokasi perencanaan. Diagram refraksi dapat dilihat pada Gambar 5 berikut.

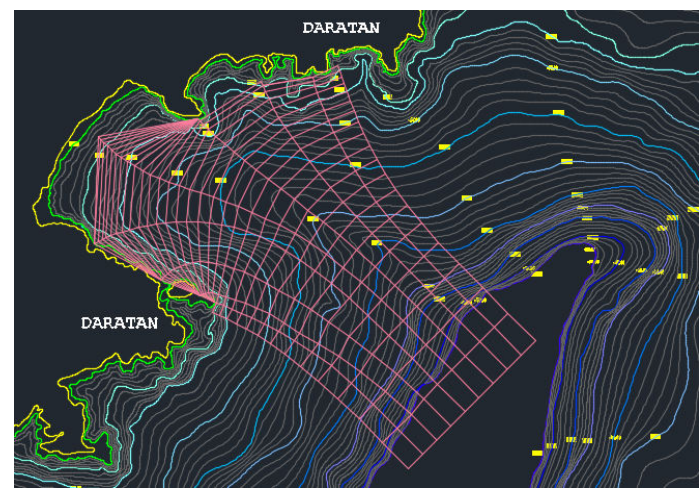

Gambar 5. Diagram Analisis Refraksi Tinggi Gelombang Periode Ulang 50 Tahun Arah Tenggara

\section{Analisis Difraksi}

Difraksi adalah peristiwa membeloknya gelombang apabila gelombang datang terhalang oleh suatu rintangan seperti pemecah gelombang atau pulau. Gelombang tersebut akan membelok di sekitar ujung rintangan dan akan masuk di daerah terlindung di belakangnya[5]. Pada Gambar 6 berikut terlihat gelombang di depan struktur yang telah terefraksi.

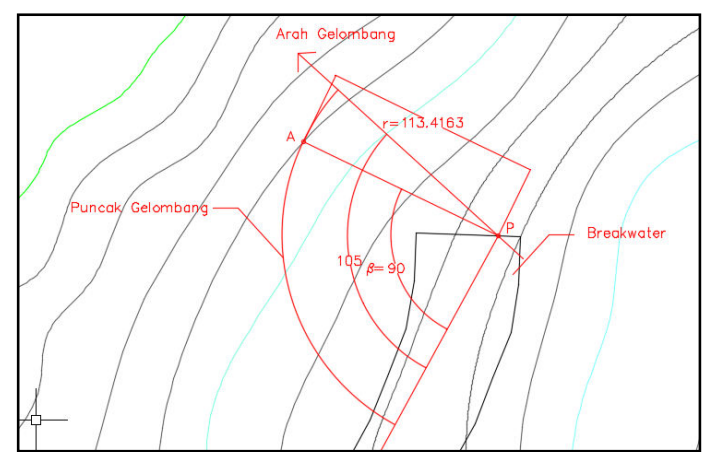

Gambar 6. Difraksi yang Terjadi pada Tinggi Gelombang di Depan Struktur

Diketahui: 


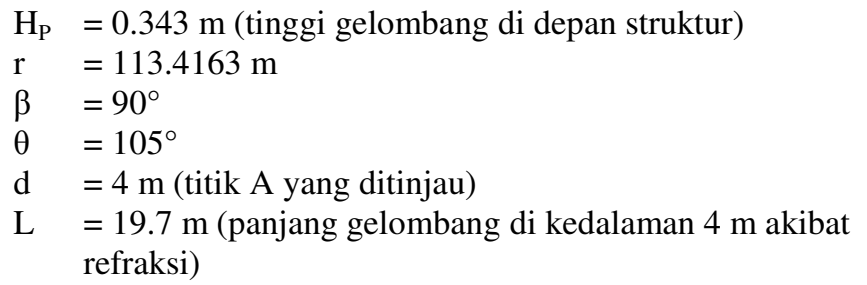

Penyelesaian:

$\frac{\mathrm{r}}{\mathrm{L}}=\frac{113.4163}{19.7}=5.75 \approx 6$

Dengan menggunakan Tabel 3.2 (Triatmodjo, 2016) untuk

$\mathrm{r} / \mathrm{L}=6 ; \theta=105^{\circ}$ dan $\beta=90^{\circ}$ didapatkan koefisien difraksi

$\mathrm{K}^{\prime}=0.256$.

Maka, tinggi gelombang di titik A:

$\mathrm{H}_{\mathrm{A}}=\mathrm{K}^{\prime} \mathrm{H}_{\mathrm{P}}=0.256 \times 0.343=0.0878 \mathrm{~m}$

\section{B. Analisis Data Pasang Surut}

Pengamatan pasang surut dilakukan pada tanggal 1 sampai dengan 15 November 2013, hasil pengamatan dapat dilihat pada Gambar 7. Data pasang surut dianalisis menggunakan Metode Admiralty [1].

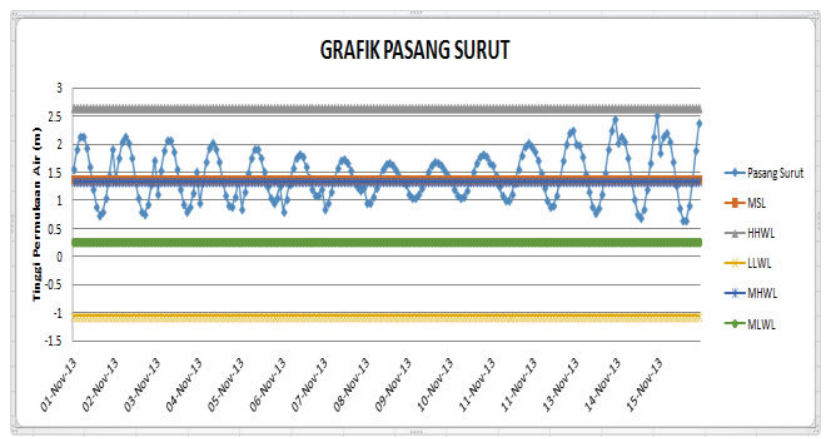

Gambar 7. Grafik Pasang Surut Teluk Sumbreng, Kabupaten Trenggalek

Berdasarkan hasil analisis pasang surut, maka didapatkan tipe pasang surut campuran cenderung tunggal, artinya dalam satu hari terjadi satu kali pasang dan satu kali surut namun pada waktu tertentu dapat terjadi dua kali pasang dan dua kali surut dengan tinggi dan periode yang berbeda. Dan didapat juga elevasi-elevasi:
- HHWL $=+2.643 \mathrm{~m}$
- $\mathrm{MHWL}=+1.34 \mathrm{~m}$
- $\mathrm{MSL}=+1.38 \mathrm{~m}$
- MLWL = +0.254 m
- LLWL $=-1.062 \mathrm{~m}$

\section{DIMENSI STRUKTUR PEMECAH GELOMBANG}

Tipe pemecah gelombang yang digunakan adalah tipe breakwater sisi miring dengan kemiringan 1:2. Material struktur bangunan menggunakan material batu pecah. Dari hasil analisis refraksi didapatkan nilai tinggi gelombang pada depan struktur adalah $0.343 \mathrm{~m}$ berada pada kedalaman $8.0 \mathrm{~m}$ di atas LWS.

Elevasi muka air rencana (Design Water Level) dihitung menggunakan rumus:

$\mathrm{DWL}=\mathrm{MHWL}+\mathrm{Sw}+\mathrm{SLR}+\Delta \mathrm{h}$
Diketahui:

$$
\begin{aligned}
\text { MHWL } & =1.34 \mathrm{~m} \\
\text { Sw } & =0.19\left[1-2,82 \sqrt{\frac{H b}{g T^{2}}}\right] H_{b} \\
& =0.19\left[1-2,82 \sqrt{\frac{3,824}{9.81 \times 11,117^{2}}}\right] 3,824=0.611 \mathrm{~m} \\
\text { SLR } & =0.38 \mathrm{~m} \\
\Delta \mathrm{h} & =0.41 \mathrm{~m}
\end{aligned}
$$

Jadi, DWL $=1.34+0.611+0.38+0.41=2.736 \mathrm{~m}$

Stabilitas struktur dihitung menggunakan Rumus Van Der Meer [3]:

Pada laut dangkal, gelombang dengan tipe surging dihitung dengan rumus:

$$
N_{s}=\frac{H_{2 \%}}{\Delta D_{n 50}}=C_{s} P^{-0.13}\left(\frac{S_{d}}{\sqrt{N}}\right)^{0.2} \sqrt{(\cot \alpha)} \xi_{m}^{p}
$$

dengan: $\Delta=\frac{\gamma_{r}}{\gamma_{a}}-1=\frac{2,65}{1,025}-1=1,585$

$$
\begin{aligned}
& \frac{H_{2} \%}{H_{S}}=1,4 \rightarrow H_{2 \%}=3,482 \times 1,4=4,8748 \mathrm{~m} \\
& C_{s}=1,4 \\
& P=0,4 \text { (faktor permeabilitas) } \\
& S_{d}=2 \text { (untuk zero damage) } \\
& N=3000 \text { (untuk laut dangkal adalah <3000) }
\end{aligned}
$$

$$
\begin{aligned}
& \xi_{m}=\frac{\tan \alpha}{\sqrt{\frac{H_{s}}{L o}}}=\frac{0,5}{\sqrt{\frac{3,482}{192,784}}}=3,72 \\
& N_{s}=\frac{4,8748}{1,585 \times D_{n 50}} \\
& =1,4 \times 0,4^{-0.13}\left(\frac{2}{\sqrt{3000}}\right)^{0.2} \sqrt{2} \times 3,72^{0,4}
\end{aligned}
$$

Sehingga didapat $\mathrm{D}_{\mathrm{n} 50}=1.58 \mathrm{~m}$

$$
\mathrm{W}_{50}=\mathrm{D}_{\mathrm{n} 50}{ }^{3} \mathrm{rr}=(1.58)^{3} 2.65=10.46 \text { ton }
$$

Setelah didapat berat butir, maka dapat dihitung dimensi struktur pada lapisan-lapisan struktur breakwater tersebut. Dengan menggunakan rumus:

- Dimensi batu

$$
D=\left(\frac{W}{r_{r}}\right)^{1 / 3}
$$

- Lebar puncak pemecah gelombang

$$
B=n k_{\Delta}\left[\frac{W}{\gamma_{r}}\right]^{1 / 3}
$$

- Tebal lapisan pelindung

$$
t=n k_{\Delta}\left[\frac{W}{\gamma_{r}}\right]^{1 / 3}
$$

- Jumlah butir pelindung

$$
N=A n k_{\Delta}\left[1-\frac{P}{100}\right]\left[\frac{\gamma_{r}}{W}\right]^{2 / 3}
$$

Struktur bangunan terdiri dari tiga lapisan yaitu Primary Layer, Secondary Layer, dan Core Layer. Berikut disajikan Tabel 3 yaitu rekapitulasi dimensi struktur bangunan tiap lapisan. Untuk gambar potongan melintang dapat dilihat pada 
Gambar 8.

Tabel 3.

Rekapitulasi Dimensi Struktur Bangunan Tiap Lapisan

\begin{tabular}{|c|c|c|c|c|}
\hline & Primary Layer & $\begin{array}{c}\text { Secondary } \\
\text { Layer }\end{array}$ & Core Layer & $\begin{array}{c}\text { Toe } \\
\text { Berm }\end{array}$ \\
\hline $\begin{array}{c}\text { Berat } \\
\text { (ton) }\end{array}$ & 10.4612 & 1.0461 & 0.0523 & 1.0461 \\
\hline $\begin{array}{c}\text { Lebar } \\
\text { Puncak } \\
\text { (m) }\end{array}$ & 5.5 & Menyesuaikan & Menyesuaikan & 2.42 \\
\hline $\begin{array}{c}\text { Tebal } \\
\text { Lapis } \\
\text { (m) }\end{array}$ & 3.6 & 1.7 & Menyesuaikan & $\begin{array}{c}\text { Menyes } \\
\text { uaikan }\end{array}$ \\
\hline $\begin{array}{c}\text { Jumlah } \\
\text { per } 10 \\
\mathrm{~m}^{2}\end{array}$ & 6 & 27 & Menyesuaikan & 27 \\
\hline $\begin{array}{c}\text { Dimensi } \\
\text { Batu (m) }\end{array}$ & 1.580 & 0.734 & 0.270 & 0.734 \\
\hline
\end{tabular}

\section{KESIMPULAN}

Dalam perencanaan bangunan pemecah gelombang di Teluk Sumbreng ini dapat ditarik beberapa kesimpulan sebagai berikut:

1. a. Kondisi pasang surut di daerah Teluk Sumbreng adalah sebagai berikut:

- $\mathrm{HHWL}=+2.643 \mathrm{~m}$

- $\mathrm{MHWL}=+1.34 \mathrm{~m}$

- $\mathrm{MSL}=+1.38 \mathrm{~m}$

- $\quad$ MLWL $=+0.254 \mathrm{~m}$

- $\quad$ LLWL $=-1.062 \mathrm{~m}$

Data-data elevasi pasang surut ini akan dipakai dalam perencanaan struktur bangunan pemecah gelombang.

b. Kondisi iklim gelombang di daerah Teluk Sumbreng dianalisis dari data angin tahun 2010-2014 didapatkan kejadian angin dominan selama 5 tahun berasal dari Arah Tenggara. Kemudian, data angin ini digunakan dalam peramalan gelombang. Dari peramalan gelombang tersebut didapatkan tinggi gelombang maksimum adalah 4.12 meter dan periode 12.091 detik.
Dari data tinggi dan periode gelombang tersebut, dihitung periode ulang 50 tahun sehingga didapat tinggi gelombang 3.482 meter dan periode 11.116 detik.

2. Kedalaman perairan di lokasi perencanaan ditinjau dari tiga titik.

- titik pertama di kedalaman -8.0 m dari LWS dengan jarak $214.5 \mathrm{~m}$ dari pantai, berarti kemiringan pantainya 0.0373 .

- titik kedua di kedalaman -7.0 m dari LWS dengan jarak $253.1 \mathrm{~m}$ dari pantai, berarti kemiringan pantainya 0.0277 .

- titik ketiga di kedalaman -6.0 m dari LWS dengan jarak $234.9 \mathrm{~m}$ dari pantai, berarti kemiringan pantainya 0.0255 .

3. Tinggi gelombang di laut dalam berdasarkan analisis hindcasting dan peramalan gelombang periode ulang 50 tahun didapatkan $\mathrm{H}_{10}$ yaitu $3.482 \mathrm{~m}$. Sedangkan tinggi gelombang rencana yang akan bekerja pada bangunan pemecah gelombang berdasarkan analisis refraksi didapatkan sebesar $0.343 \mathrm{~m}$.

4. Dimensi struktur bangunan pemecah gelombang dihitung menggunakan Rumus Van Der Meer sebagai berikut:

- Primary Layer

Dimensi batu $=1.58 \mathrm{~m}$

Lebar puncak $=5.5 \mathrm{~m}$

Tebal lapis $=3.6 \mathrm{~m}$

- Secondary Layer

Dimensi batu $=0.734 \mathrm{~m}$

Tebal lapis $=1.7 \mathrm{~m}$

- Core Layer

Dimensi batu $=0.27 \mathrm{~m}$

\section{DAFTAR PUSTAKA}

[1] B. Triatmodjo, Teknik Pantai. Yogyakarta: Beta Offset, 2016.

[2] U.S. Army Corps of Engineers, Coastal Engineering Manual Part II-A. Washington, 2002.

[3] CIRIA, "Manual on The Use of Rock in Coastal and Shoreline Engineering," London, 1991. 


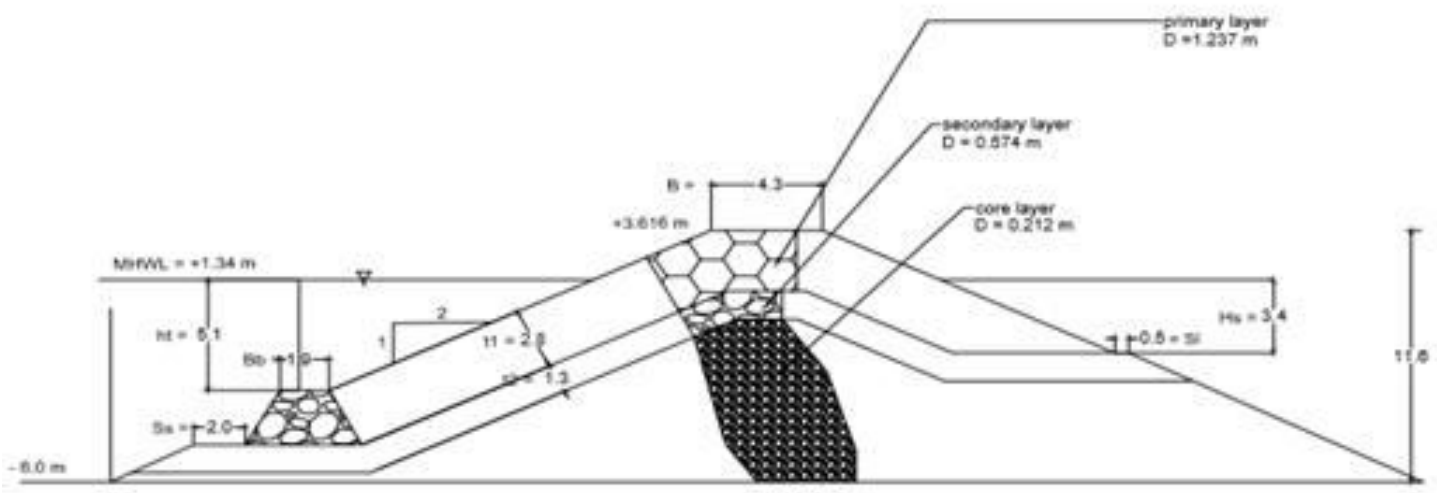

Gambar 8. Potongan Melintang Breakwater Sisi Miring dengan Material Batu Pecah 